\title{
IMPORTANCE OF THE PROTECTION OF PRIVACY OF JUVENILE SUSPECTS OR ACCUSED PERSONS IN CRIMINAL PROCEEDINGS IN THE CONTEXT OF THE EU LAW
}

\author{
Ivana Radić, PhD, Postdoctoral Researcher \\ University of Split, Faculty of Law \\ Domovinskog rata 8, Split, Croatia \\ iradic@pravst.hr
}

\begin{abstract}
The protection of privacy of juvenile suspects or accused persons in criminal proceedings is one of the fundamental principles of juvenile criminal procedure. The aim of this right is to prevent any unnecessary stigmatisation and labelling of juveniles suspected/accused as perpetrators (of criminal act) by their peers or others in their community. The involvement in a formal criminal proceeding can be very stressful for a juvenile and affect their further development and mental health. The protection of privacy during criminal proceeding helps them in their rehabilitation and reintegration into society after conviction. Countries usually protect the juveniles 'right to privacy by closing the criminal proceeding for general public and by restricting the disclosure of information about criminal proceedings involving juveniles as suspects or accused persons to the media. In practice, this means that a limited number of people in criminal justice system has the right to access information about suspected/accused juveniles. Unfortunately, the present-day media often neglect this right and use information about juveniles in criminal proceeding in their news reports in a sensationalist way in order to increase their circulation. That kind of practice shows that this right is considered irrelevant and that the media and general public do not have appropriate knowledge about the importance and reasons why this right has been incorporated into the juvenile criminal procedure. This paper analyses the importance of the protection of privacy of juveniles who are suspects or accused persons in criminal proceeding according to the international documents, ECHR, the relevant case law and the Directive EU 800/2016 with reference to the legislative solutions found in some EU Member States including Croatia.
\end{abstract}

Keywords: protection of privacy, juveniles, criminal proceeding, Directive 2016/800 


\section{INTRODUCTION}

Private life refers to different areas of human life that are intertwined, including privacy and secrecy. This aspect of life includes different life facts that should be inaccessible to other people (secret sphere) or available exclusively to certain people (private sphere). The private sphere implies the relationships with family and friends, and the secret sphere refers to a considerably smaller circle, usually only one person. ${ }^{1}$ If that part of someone's life is violated, it can cause damage to their quality of life, affect their emotions, mental health and their social and family life. A juvenile's private life refers to his/her identity, mental integrity, public image, participation in creating an image of himself/herself, understanding the perception and interpretation of his/her life and himself/herself. ${ }^{2}$

Research shows that juveniles, due to their developmental stage, may not have obtained the cognitive abilities required to fully understand and effectively participate in juvenile justice proceedings yet. Their general intellectual ability, verbal ability, attention and executive functioning significantly improve with age but during developmental stage it is necessary to offer them help and guidance, especially during difficult times. ${ }^{3}$ Juveniles should be considered particularly vulnerable because they are at a greater risk of being discriminated or deprived of their fundamental rights on account of their age, incomplete physical and psychological development, lack of knowledge or the ability to act by exercising free will. ${ }^{4}$

Cases when a juvenile is a suspect or accused in criminal proceeding represent significantly stressful situations that the juvenile should not have to experience alone and without help. One of the ways that can help him/her overcome that experience a little bit easier is to ensure that his/her privacy is respected and protected during that time. Therefore, the protection of privacy has become one of the fundamental principles of juvenile criminal procedure. The protection of privacy is important because it helps to prevent the unnecessary stigmatisation of juveniles, possible humiliations or embarrassments that they may experience after being suspected or accused in criminal proceeding. Once a juvenile has been labelled as a "criminal" within his social environment (neighbourhood, school, sports club),

1 Gabelica Šupljika, M., Psihološki aspekt prikaza djeteta u medijima u Zaštita privatnosti djece u medijima, Zbornik priopćenja s tribine, Pravobranitelj za djecu, Zagreb, 2009, p. 20

$2 \quad$ Ibid., p. 21

3 Liefaard, T.; van den Brink, Y., Juveniles Right to Counsel during Police Interrogations: An Interdisciplinary Analysis of a Youth-Specific Approach, with a Particular Focus on the Netherlands, Erasmus Law Review, December 2014, no. 4, p. 214-215

4 Radić, I., Right of the child to information according to the Directive 2016/800/EU on procedural safeguards for children who are suspects or accused persons in criminal proceedings, in: Duić, D.; Petrašević, T. (eds.), EU and comparative law issues and challenges series-issue 2, 2019, p. 470 
it is very difficult to discard the ensuing stigma and reintegrate into normal life. Hence, the right to the protection of privacy is substantially relevant for the effective participation of juveniles in justice proceedings. In order to protect the juvenile and help him/her in the process of resocialisation and reintegration into society, many countries have decided to close criminal proceedings involving juveniles to general public and the media, which means that only a limited number of people are entitled to attend the main hearing or trial. ${ }^{5}$ However, in juvenile cases, the right to a public hearing, which is designated to benefit the defendant as one of the crucial elements of the right to a fair trial ensuring transparency of the criminal proceeding and full accountability of official actors, can harm the integrity of the juvenile and is, therefore, not perceived to be in the best interest of the juvenile. Hence, this requires special interpretations of Art. $6 \mathrm{ECHR}^{6}$ in terms of juvenile offenders, otherwise the principle of a fair trial could be reversed. ${ }^{7}$

Since the media have a major role in protecting this right, they have considerably benefited the interests of the juveniles by emphasising different problems regarding juveniles, the lack of political will and the social standard of protection related to this issue. Furthermore, they endorsed juveniles in different aspects of their lives by reporting, for instance, about their academic or sports achievements. ${ }^{8}$ However, there have also been some less favourable examples of media's coverage of specific juvenile cases, especially in the last few years, where they severely disrupted the juveniles' privacy or exposed elaborate details of their personal or family life, which, in view of the above, is considered unacceptable.

\section{THE RIGHT TO PROTECTION OF PRIVACY OF JUVENILE SUSPECTS IN INTERNATIONAL DOCUMENTS ${ }^{9}$}

The Beijing Rules ${ }^{10}$ emphasise the importance of protection of a juvenile's privacy during all stages of the criminal proceedings in order to avoid unnecessary public-

5 Gensing, A., Criminal procedure; in Dünkel, F. et al. (eds.), Juvenile Justice Systems in Europe, Current Situation and Reform Developments, vol. 4, 2011, Forum Verlag Godesberg, p. 1638

6 European Convention on Human Rights, opened for signature in Rome on 4 November 1950 and came into force in 1953, [https://www.echr.coe.int/Documents/Convention_ENG.pdf], accessed 20. June 2020

7 Kovačević, M., Maloletničko pravosuđe u Evropi i maloletnici kao aktivni učesnici krivičnog postupka, Zbornik PF u Splitu, vol. 51, no. 4, 2014, p. 880

8 Gabelica Šupljika, op. cit., note 1, p. 20

9 In this part of paper author uses the term child as a synonym for juvenile because most of the international documents uses the term child. The child is always defined as person under the age of 18 which includes juveniles.

10 United Nations Standard Minimum Rules for the Administration of Juvenile Justice ("The Beijing Rules"), Adopted by General Assembly resolution 40/33 of 29 November 1985 
ity or the stigmatisation of the juvenile. Hence, no information that could lead to the identification of a juvenile should be published. ${ }^{11}$

The right to the protection of privacy is broadly stipulated to cover every child in every situation in the UN Convention on the rights of the child (UN CRC). ${ }^{12}$ The provisions regulating the child's right during criminal proceeding state that the child's right to privacy should be respected during all stages of the proceedings. ${ }^{13}$ According to the General Comment No. 10 on CRC, ${ }^{14}$ the aim of the right to the protection of privacy of children is to avoid the harm caused by undue publicity or by the labelling process. In order to achieve this level of protection, the Member States should ensure that no information that may lead to the identification of the child offender be published, while the court hearings of an accused child should take place behind closed doors. The judgement/sentence should be pronounced publicly at the court session but without revealing the identity of the child. The media has a significant role in protecting this right, therefore the journalist who violate this right should be sanctioned with the appropriate disciplinary or even, in some cases, penal measures. ${ }^{15}$ The CRC Committee states that the right to the protection of privacy may be related to the notion that juveniles should be able to express their views freely, which means that they can express their views without pressure, that would eventually help them decide whether they want to exercise their right to be heard in criminal proceedings. The protection of privacy prevents stigmatisation, social isolation and negative publicity of the child, all of which can hamper their reintegration into society. ${ }^{16}$ The CRC Committee has also taken the stand that the trial in camera (i.e. behind closed doors) should be the rule, while the exceptions should be very limited and justified in writing by the court, taking into account the best interests of the juvenile. ${ }^{17}$

11 The Beijing Rules, Rule 8.

12 Convention on the Rights of the Child (CRC,) General Assembly Resolution 44/25 of 20 November 1989, entry into force 2 September 1990

13 UN CRC, art. 16. and art. 40 (2) vii

14 UN Committee on the Rights of the Child (CRC), General comment No. 10 (2007): Children's Rights in Juvenile Justice, 25 April 2007, CRC/C/GC/10, available at: [https://www.refworld.org/ $\operatorname{docid} / 4670 \mathrm{fca} 12 . \mathrm{html}$ ], accessed 13 . July 2020

15 CRC/C/GC/10, p. 18-19

16 See more: Derenčinović, D.; Getoš, A.: Uvod u kriminologiju s osnovama kaznenog prava, Zagreb, 2008, p. 147-150; Cvjetko, B.; Singer, M., Kaznenopravna odgovornost mladeži u praksi i teoriji s prilozima i literaturom, Zagreb, 2011, p. 147-151

17 See: General Comment No. 12, para. 61; see also General Comment No. 10, para. 65. Manual: Can anyone hear me?, Participation of children in juvenile justice: A manual on how to make European juvenile justice systems child-friendly, IJJO, Published by the International Juvenile Justice Observatory (IJJO), 2016, Belgium, p. 45 
The protection of private and family life is stated as one of the general elements of child-friendly justice in the Guidelines on child-friendly justice (hereinafter: Guidelines). ${ }^{18}$ The Guidelines state that the privacy and personal data of children who are or have been involved in judicial or non-judicial proceedings should be protected in accordance with the national law. The Member States should provide that no information or personal data potentially revealing the child's identity is made available or published, particularly by the media. The national law should have implemented rules that allow only a limited access to records or documents containing personal and sensitive data of children, especially when they are involved in judicial proceedings. In addition, whenever children are being heard or giving evidence in judicial proceedings, they should preferably be heard in camera, and only those directly involved should be present. ${ }^{19}$ The protection of personal data of children should be ensured especially in relation to the mass media. The Member States should provide special legislative measures for the media and adopt positive obligations to monitor legally binding or professional codes of conduct for the press. ${ }^{20}$

The right to privacy is described as a vitally important right in the Guidelines on child-friendly legal aid. ${ }^{21}$ The aim of this right is to protect the child from discrimination and stigmatisation that could occur if the information about the child's offence is widely publicised. The problem is that not many legal professionals recognise the risks implied for children in the situations when this right is not respected. Therefore, both the legislation and the practitioners should ensure that the court hearings involving children are held in private, the child's identity is not revealed in the judgments, the details of the case are exposed only to a limited number of people and that the media never discloses information that could lead to a breach of child's privacy. The legal professionals have a major role in the protection of the child's privacy, hence they should ensure that the child's personal data are protected and kept confidential in accordance with the national law. The exception to this rule can be permitted in national legislation in exceptional circumstances. $^{22}$

18 Guidelines of the Committee of Ministers of the Council of Europe on child-friendly justice, adopted by the Committee of Ministers of the Council of Europe on 17 November 2010 and explanatory memorandum, Council of Europe Publishing, 2010, p. 22

19 Guidelines, part IV., 2. 6. - 2. 10., p. 22

20 If the identity of the child is revealed that could cause an irreparable damage to the child. Guidelines, IV. A., 2. 8., pp. 22., IV.A., 2.60., p. 64

21 Guidelines on child friendly legal aid, UNHCR, UNICEF's Europe and Central Asia Regional Office (ECARO), October 2018, [https://www.unicef.org/eca/sites/unicef.org.eca/files/2018-11/Guidelines\%20on\%20Child-Friendly\%20Legal\%20Aid\%20UNICEF\%20ECARO\%202018.pdf], accessed 20. June 2020

22 Guidelines on child friendly legal aid, Guideline 9, Privacy and confidentiality, p. 30-31 
Recommendation No. $\mathrm{R}(87) 20^{23}$ also states that in criminal proceedings against juveniles their right to a private life should be respected in order to reinforce their legal position throughout the proceedings, including the police investigation. ${ }^{24}$ Recommendation $\mathrm{CM} / \operatorname{Rec}(2017) 3^{25}$ indicated that any individual's case records should be disclosed only to those that have the right to receive them and they should receive only limited information relevant to their legitimate purpose. In fact, the basic principle should be that the information in the individual's case records is confidential. ${ }^{26}$

Juvenile's right to privacy must be respected during all stages of the criminal proceeding according to Recommendation $\mathrm{CM} / \operatorname{Rec}(2008) 11 .{ }^{27}$ The identity of juveniles and confidential information about them and their families can not be conveyed to anyone who is not authorised by law to receive it. ${ }^{28}$ Protection of privacy of juveniles must also be respected when dealing with juveniles criminal case records, during deprivation of liberty of juveniles, his/her accomodation in institution during deprivation of liberty, during the search and transfers between institutions. ${ }^{29}$

\subsection{Protection of juveniles' privacy in ECtHR case law}

It is generally accepted that children enjoy all rights under ECHR, even though ECHR does not explicitly refer to children's rights. ${ }^{30}$ In several cases, the European Court for Human Rights (ECtHR) has also recognised that the safeguards

23 Recommendation No. R (87)20 of the Committee of Ministers to member states on social reactions to juvenile delinquency, Adopted by the Committee of Ministers on 17 September 1987at the 410th meeting of the Ministers' Deputies

24 Recommendation No. R (87)20, part III., point 8

25 Recommendation CM/Rec (2017) 3 on the European Rules on community sanctions and measures, Adopted by the Committee of Ministers on 22 March 2017 at the 1282nd meeting of the Ministers' Deputy

26 Recommendation CM/Rec (2017) 3, part II., point 47. Recommendation specially stipulates that agencies that work with juvenile during community sanctions and measures should draw up inter agency agreements to try to regulate information exchange between them about juveniles involve in the process

27 Recommendation CM/Rec (2008) 11 of the Committee of Ministers to member states on the European Rules for juvenile offenders subject to sanctions or measures, Adopted by the Committee of Ministers on 5 November 2008 at the 1040th meeting of the Ministers' Deputies

28 Part A- Basic principles, art. 16, Recommendation CM/Rec (2008) 11

29 See: part D.1. 34.2.b); part E. 5. 63. 1; part E. 13. 2. 89. 1; part E. 14. 99. 3. Recommendation CM/ $\operatorname{Rec}(2008) 11$

30 T and V vs. U.K., ECHR 16.12.1999, 24724/94 and S.C. vs. U.K., ECHR15.06.2004, 60958/00. Carić, A.; Kustura, I., Kamo ide hrvatsko maloljetničko kazneno zakonodavstvo, Zbornik radova PF Split, vol. 47 , no. 4, 2010, p. 806-808 
provided for in Art. 6 also apply, inter alia, to administrative proceedings against juveniles. ${ }^{31}$

One of the elements of the right to a fair trial stated in Article 6 is the right to a public hearing, which is considered as one of the fundamental principles of any democratic society. ${ }^{32}$ Despite the above mentioned, this right can also be subject to exceptions. ECHR states that "...press and public may be excluded from all or part of the trial ... where the interests of juveniles or the protection of the private life of the parties so require...". ${ }^{33}$ Conducting proceedings, whether entirely or partly, in camera must be strictly required by the circumstances of the case (Welke and Biatek v. Poland, $\$ 74$; Martinie v. France [GC], $\$ 40$ ). If the authorities believe that there are grounds for applying one of the exceptions mentioned in Art. 6 , they are entitled to order that the hearings be held in camera. The domestic courts are required to provide sufficient reasoning that their decision falls under the exceptions mentioned in Article $6(1) .{ }^{34}$ The right to a public hearing and the right to public pronouncement of a judgment are two separate rights under Article 6 . The fact that one of these rights is not violated does not in itself mean that the other right cannot be breached. ${ }^{35}$

In the course of years, ECtHR has developed certain standards in the case law that relate to juvenile criminal law including the right to the protection of privacy and personal data of the accused child. ${ }^{36}$ Article 6 provides for special safeguards regarding sensitive data, such as personal data related to criminal convictions. Other categories of data could be defined as sensitive by the domestic law or treated as such by public authorities allowing for a better protection of children's privacy. ${ }^{37}$

31 See cases Adamkiewicz vs. Poland, 2 March 2010, appl. No. 54729/00, section 4; Blokhin v. Russia, 14 November 2013, app. No. 47152/06, section 1. In the case Blokhin vs. Russia ECtHR, the Court decided that the relevant administrative proceedings were criminal in nature and doing so the Court moved along the traditional lines of the Engel case-law. See: de Vocht D. et al., Procedural Safeguards for Juvenile Suspects in Interrogations: A Look at the Commission Proposal in Light of an EU Comparative Study, New journal of European criminal law, vol. 5, no. 4, 2014, p. 485-486

32 Guide on Article 6 of the Convention - Right to a fair trial (criminal limb), European Court of Human Rights, Council of Europe, updated on 31 December 2019, p. 47

33 ECHR, art. 6 (1)

34 See: Chaushev and Others v. Russia, $\$ 24$., Guide on Article 6 of the Convention - Right to a fair trial (criminal limb), op. cit., note 32, p. 51-52

35 Ibid., p. 52

36 See more: Horvat, L., Postupovna jamstva za djecu koja su osumnjičena ili optužena u kaznenim postupcima sukladno Direktivi 2016/800/EU, HLJKPP; vol. 25, no. 2, 2018, p. 579-583

37 Some example of data that could be defined as sensitive: disciplinary proceedings, recording cases of violence, medical treatment in school, school orientation, special education for disabled people and social aid to pupils from poor families. From: Guidelines on child friendly justice, op. cit., note 18, p. 65 
In two important cases, ECtHR discussed the child`s right to privacy and protection of personal data in situations when the child is accused of committing a very serious offence that attracted a high level of media and public interest. In the cases V. v. the United Kingdom and T. vs. UK, the Court stated: "[...] it is essential that a child charged with an offence is dealt with in a manner which takes full account of his age, level of maturity and intellectual and emotional capacities, and that steps are taken to promote his ability to understand and participate in the proceedings." ${ }^{38}$ In addition, the Court stated: "...It follows that, in respect of a young child charged with a grave offence attracting high levels of media and public interest, it would be necessary to conduct the hearing in such a way as to reduce as far as possible his or her feelings of intimidation and inhibition." ${ }^{39}$

The Charter of Fundamental Rights of the $\mathrm{EU}^{40}$ states that everyone has the right to the respect of his or her private and family life, home and communications and everyone has the right to the protection of personal data. ${ }^{41}$ In a specific provision addressing children's rights, the Charter indicates that children have the right to such protection and care as is necessary for their well-being and that in all actions relating to children the child's best interests must be a primary consideration. ${ }^{42}$

Despite the fact that the previously mentioned international documents are considerably important, many of the contained norms are of general nature, and the majority of them are not binding for the Member States. One of the underlying issues is that only a few of them are concerned with the protection of the children's rights in the early stages of the criminal procedure, when the children are most vulnerable. ${ }^{43}$

\section{PRIVACY PROTECTION OF JUVENILE PERPETRATORS IN THE JUVENILE JUSTICE SYSTEM OF EUROPEAN COUNTRIES}

Criminal proceedings for adults are open to the public in all European countries because a public hearing is one of the crucial elements of the rule of law principle enshrined in Art. 6 ECHR. However, because of a widely accepted principle that juveniles involved in judicial proceeding need more protection, it has become a

\footnotetext{
38 V. v. UK, No. 24888/94, paragraph 86, T v. UK, No. 24724/94, paragraph 84

39 V. v. UK, No. 24888/94, paragraph 87, T v. UK, No. 24724/94, paragraph 85. In both of these cases, the Court decided that there has been a breach of Article 6 (1) of the Convention

40 Charter of the Fundamental Rights of the EU, OJ C 326/395, 26. 12. 2012

${ }_{41}$ Charter of the Fundamental Rights; Art. 7 and 8. The Charter also states that the compliance with the rules regarding protection of personal data shall be subject to control by an independent authority

42 Charter of the Fundamental Rights; Art. 24

43 de Vocht, et al., op. cit., note 31, p. 482
} 
general rule that the public and the media are excluded from the criminal proceeding involving juveniles as accused/suspects or as victims or witnesses. ${ }^{44}$

The right to privacy of juvenile suspects or accused persons in criminal proceeding is protected in all EU Member States (MS). All MS try to find a balance between the right to privacy and the right to freedom of information and expression. In some MS (e.g. Austria, Portugal, Sweden), the legislation provides for a general rule that the information about the criminal proceeding involving a juvenile suspect or accused person can be disclosed, but in those countries the judges have a discretionary power to order the non-disclosure of any information about the juvenile if they consider it to be in the their best interest. ${ }^{45}$ In contrast, in some other countries (e.g. Italy, Netherlands, UK) the legislation gives priority to the juvenile's right to privacy and the judges have a discretionary power to order a disclosure of information regarding the juvenile if they believe that it is necessary in order to achieve the legitimate aim such as freedom of information. ${ }^{46}$ Interestingly, the existence of juvenile courts in a country is no clear guarantee of the non-publicity of proceedings. There are differences between the countries in terms of whether the exclusion of public also covers the rendition of the judgement and whether the criminal proceeding is public or non-public from the onset. ${ }^{47}$

In half of the EU countries, when a juvenile is a suspect/accused person in criminal proceeding, the proceedings are held in camera (in the absence of the general public) but with the possibility of public access under certain conditions. In the other half of the EU countries, the situation is reversed, which means that the proceedings are open to public with the possibility of exclusion due to the offender's age or educational reasons. ${ }^{48}$

The majority of EU MS have adopted different forms of legislative solutions that regulate the media's coverage of the judicial proceedings involving juveniles, and in many states the bans on publicity are more strict in cases of suspect/accused juveniles

\footnotetext{
44 Gensing, op. cit., note 5, p. 1639

45 Summary of contextual overviews on children's involvement in criminal judicial proceedings in the 28 MS of the EU, European Commission - Directorate-General for Justice, Luxembourg, Publications Office of the European Union, 2014, p. 38

46 Ibid. In those countries the basic for an exclusion of publicity is not only the fact that juveniles need more protection but legislation often gives some other special grounds upon which the judge can decide to base the non-publicity so that more proceedings can in fact be held in camera. Gensing, $o p$. cit., Note 5, p. 1639

47 For example, in Croatia, Netherlands, Czech Republic and Austria the final judgment is always to be pronounced publicly. Art. 6. (2) al. 2 ECHR stipulates that renditions of judgment must be open to the public. Gensing, op. cit., note 5, p. 1639

$48 \quad$ Ibid, p. 1640-1641
} 
than in the cases of juveniles as victims or witnesses. ${ }^{49}$ In all EU MS it is prohibited to broadcast the names or other information that could be used to identify the juvenile as a suspect/accused person. This approach, which has been accepted in order to avoid unnecessary humiliation, identification and exposure, is common to all countries. ${ }^{50}$

The juveniles value being heard in cases that affect them, and if they actively participate in the decision-making process, it helps them to understand and accept the final decision. ${ }^{51}$ Research has shown that there is a connection between the right of the juvenile to express their views freely and the conducting of juvenile justice proceedings behind closed doors. The layout of and the atmosphere in the courtroom also influence the way that the suspect/accused juvenile feels and the way that he/she can effectively participate in the court hearing. Certain research has shown that in some countries (e.g. Switzerland, Belgium, France and the Netherlands) when the court hearing is held in chambers, the informal atmosphere, the limited number of participants in the court hearing and less social and physical distance between the participants contribute to the juvenile`s more effective participation in the criminal proceedings. It has also been concluded that in this type of hearings the judge examines not only the personal and family situation of the juvenile but he/she also discusses the criminal offence committed by the juvenile and provides the juvenile with more explanations of the court procedure. ${ }^{52}$

Another issue to be covered within the domain of protection of privacy is the adoption of special legislative provisions on the registration of offences. This particularly refers to the obligation to disclose past convictions, the accessibility of criminal records for future references in later proceedings, special provisions regarding exchange of information about children involved in criminal proceeding and data from the criminal record of a child. The exact form of such provisions varies significantly from country to country. ${ }^{53}$

\section{PRIVACY PROTECTION OF JUVENILE PERPETRATORS IN CRIMINAL PROCEEDINGS BY THE DIRECTIVE 2016/800}

Since recently, the children's rights have been addressed structurally and in a coordinated fashion across the EU legislation and policymaking, whereas in the past it

\footnotetext{
49 Summary of contextual overviews on children s involvement in criminal judicial proceedings in the 28 MS of the EU, op. cit., note 45, p. 38

50 Gensing, op. cit., note 5, p. 1641

51 Rap, S., A Children's Rights Perspective on the Participation of Juvenile Defendants in the Youth Court, International Journal of Children's Rights, vol. 24, 2016, pp. 100

52 Ibid., p. 104-105

53 Gensing, op. cit., note 5, p. 1641
} 
occurred in a piecemeal fashion..$^{54}$ Directive $2016 / 800{ }^{55}$ sets up a list of minimum rights that the juveniles who are suspects or accused persons in criminal proceedings in all EU MS should have during the criminal proceedings, including, inter alia, the right to the protection of privacy. In fact, one of the key features of the Directive as a whole is the emphasis on protecting the rights and providing safeguards at the earliest stages of proceedings when the suspected and accused juveniles are most vulnerable. ${ }^{56}$ The Directive states that MS should ensure that the privacy of juveniles is protected during the criminal proceedings and that they should provide that the court hearings involving juveniles are held in the absence of the public, or allow the courts or judges to decide to hold such hearings in the absence of the public. ${ }^{57}$

In the adoption process of the Directive, there were different opinions on how to regulate this right so that it could be implemented in all MS because of the differences between the legal traditions and systems across the MS. ${ }^{58}$ It was decided that the Directive should accept a solution that will be a balance between the best interest of the juvenile and the general principle of a public hearing as one of the elements of the rule of law in accordance with Article 6 ECHR. Therefore, it was decided that the MS should provide in their national legislation that the court hearings involving juveniles are usually held in the absence of the public or that the courts or judges have the right to decide if such hearings should be held in the absence of the public. It is up to the MS to decide what kind of legislative solution works in their national legislation and practice. ${ }^{59}$ The implementation of this right is without prejudice to the judgments being pronounced publicly in accordance with Article 6 ECHR. ${ }^{60}$

54 Rap, S., et al., White Paper on the EU Directive 2016/800, Key aspects, priorities and challenges for implementation in the EUMS, IJJO, p. 8

55 Directive 2016/800/EU of the European Parliament and of the Council of the 11 May 2016 on the procedural safeguards for children who are suspects or accused persons in criminal proceedings (21.5.2016), OJ L 132/1. For more about the Directive see: Rap, S. E.; Zlotnik, D., The Right to Legal and Other Appropriate Assistance for Child Suspects and Accused Reflections on the Directive on Procedural Safeguards for Children who are Suspects or Accused Persons in Criminal Proceedings, European Journal of Crime, Criminal Law and Criminal Justice, vol. 26, 2018, p. 110-118; Radić, op. cit., note 4, p. 470473

56 Directive includes principles enshrined in binding and non-binding standards, such as the CRC, the case law of the ECtHR and the Council of Europe Guidelines on Child-friendly Justice. Rap; Zlotnik, op. cit., note 54, p. 117

57 Directive, Art. 14 (1 and 2)

58 Directive, para. 56

59 Cras, S., The Directive on Procedural Safeguards for Children who Are Suspects or Accused Persons in Criminal Proceedings, Genesis and Descriptive Comments Relating to Selected Articles, Eucrim, No. 2, 2016, p. 118

60 Directive, para. 56 
The Directive also states that the MS should take appropriate measures to ensure that the audio-visual recording of questioning of the suspect/accused juvenile is not made public. ${ }^{61}$ This means that the information, such as images of the suspect/ accused juvenile, that could lead to the identification of the juvenile should not be made public. Certain proposals were made regarding the derogations to this obligation, for example in the situations when giving information about the juvenile's identity to the public could be in the interest of the criminal proceedings (cases of sexual assault), however they were not accepted. ${ }^{62}$

Since the media plays a significant role in the execution of the right to privacy in every MS, the Directive also states that the MS should encourage the media to take self-regulatory measures in order to achieve the protection of privacy for juveniles in practice, all taking into consideration and respecting the freedom of expression and information and freedom and pluralism of the media. ${ }^{63}$

\section{PRIVACY PROTECTION OF JUVENILE PERPETRATORS IN THE CROATIANS LEGISLATION}

The protection of privacy is stipulated in the Croatian Constitution ${ }^{64}$ and it refers to the protection of privacy of family and personal life and the protection of personal data. ${ }^{65}$ In addition, it indicates that the state and all societal stakeholders are obligated to protect the children and youth. ${ }^{66}$ On the other hand, the Constitution also guarantees the freedom of the media to report the information to the public. ${ }^{67}$

In Croatia, the legal status of juveniles ${ }^{68}$ who are suspects or accused of committing a criminal offence is regulated by special law, The Youth Courts Act (hereinafter: YCA) ${ }^{69}$ Croatia has implemented Directive 2016/800 into the YCA at

\footnotetext{
61 Directive, Art. 14 (3)

62 Cras, op. cit., note 59, p. 118

63 Directive, Art. 14 (4)

64 Constitution of the Republic of Croatia, Official Gazette, No. 56/90, 135/97, 08/98, 113/00, 124/00, 28/01, 41/01, 55/01, 76/10, 85/10, 05/14

65 Constitution, Art. 35 and 37

66 Constitution, Art. 63

67 Constitution, Art. 38

68 In Croatia the term "juvenile" is used for children that are criminally liable. A 'juvenile' is a person who, at the time of committing an offence, was at least 14 years but under 18 years of age. (YCA, Art. 2)

69 Youths Courts Act (Zakon o sudovima za mladež), Official Gazette No. 84/2011, 143/2012, 148/2013, $56 / 2015,126 / 2019$. Name of the act in Croatian language is Zakon o sudovima za mladež. There is no official translation of the Act in English and the author will use the term Youths Courts Act in this paper. YCA is lex specialis in regard to the Criminal Code, Criminal Procedure Act, Courts Act and
} 
the end of $2019 .^{70}$ One of the basic elements of criminal proceeding against the juveniles in Croatia is that the court hearings are always held in camera, in the absence of the public. The public is excluded from the court hearing primarily to avoid the stigmatisation and labelling of the juvenile in his/her close environment and, secondly, to avoid gaining popularity among his/her peers due to the committed crime. ${ }^{71}$ When implementing Directive 2016/800, the Croatian legislation decided that the implementation of the right to the protection of privacy in the YCA is not necessary because the YCA has already been harmonised with the requirements of the Directive. ${ }^{72}$

The right to the protection of privacy is prescribed in a number of legal provisions of the YCA. According to the YCA, the provisions of the Criminal Code ${ }^{73}$ about the public pronouncement of a judgement do not apply to criminal proceedings against juveniles (Art. $34 \mathrm{YCA}$ ), the criminal investigation and proceeding against juveniles are secret, the content and the course of the criminal proceeding against juveniles or the decision made in that proceeding cannot be published without the approval of the competent authority (Art. 60 (1) and (2)) $)^{74}$, the participants in the criminal proceedings against juveniles are warned that the proceeding is secret and that the disclosure of a secret or confidential information that they hear during the criminal proceeding is considered a criminal offence (Art. 75 (3)). In addition to these basic provisions, the principle of protecting the privacy of juveniles during criminal proceeding can also be found in other articles: juveniles are brought to court without restraint by police officers in civilian clothes (Art. 55 (2)); any decisions made in relation to juveniles cannot be published on the bulletin board of the court house (Art. 55 (4)); only the persons listed in the legislation can be present during the judicial council session (Art. 84(1)) and during a court hearing (Art. 86 (2)). The persons engaged in the protection and upbringing of juveniles or the suppression of juvenile delinquency and the researchers may be allowed by the court to attend the hearing (Art. 86 (4)). If it seems necessary during the hearing, the court may order that all or some persons be removed from the hearing

other general regulations. These acts will be applied to juvenile only if the matter in question is not regulated otherwise by the YCA. YCA, Art. 3

70 YCA, Official Gazette No. 126/2019

71 Carić, A., Kazneni postupak prema maloljetnicima, Split, 2004, p. 13

72 Prijedlog Zakona o izmjenama i dopunama ZSM-a, Vlada RH, lipanj 2019, Zagreb, p. 26

73 Criminal Code (Kazneni zakon), Official Gazette No. 125/11., 144/12., 56/15., 61/15., 101/17., 118/18., 126/19.

74 Only those part of the criminal proceeding towards juveniles that the juvenile court or public prosecutor has approved can be published but, even then, the name of the juvenile or any information about the juvenile that could reveal the identity of the child cannot be published. YCA, Art. 60 (3) 
(Art. 84 (4) and (5)). The data from the records on educational measures may be provided only to certain services for intended purposes (Art. 23).

The question of protection of privacy of juveniles during pre trial proceeding is also protected by YCA because it is stated that the criminal investigation against juveniles is secret (Art. 60 (1) YCA). This means that juvenile has the right to protection of privacy during the earliest possible stage of criminal proceeding when juveniles are most vulnerable. ${ }^{75}$ Police officers who are trained to work with children are obligated to protect the privacy of children involved in criminal proceeding according to the Act on Police Affairs and Powers (Art. 18) ${ }^{76}$

In addition to the YCA, the protection of privacy of juveniles involved in criminal proceeding as suspects/accused persons or victims is regulated by different legislative enactments in Croatia. The right to the protection of privacy of children is also mentioned in the Social Welfare Act, Criminal Procedure Act, Criminal Code and Family Act. ${ }^{77}$ In the Croatian Criminal Code, there is a special criminal offence titled the violation of the child's privacy that states "Whoever brings or conveys something from the child's personal or family life, publishes a child's photograph or reveals the child's identity, which caused the child anxiety, ridicule from peers or other persons or otherwise endangers the child's well-being, shall be punished by imprisonment for a term not exceeding one year." 78 If said criminal offence has been committed by an official or through different media outlets (e.g. press, radio, television, internet), then it is considered as an aggravated form of the criminal offence. ${ }^{79}$ The aim of this criminal offence is not only to protect the privacy of a child but also the child's well-being and development. In fact, frequent articles in the media where, without any protection of identity, the photos of children were published and their names and surnames mentioned, connecting them to the situations that can cause anxiety in children or generally endanger the child's well-being, are the main reason why this criminal offence was incorporated into the Criminal Code. ${ }^{80}$

75 Directive 2016/800 applies in criminal proceedings even before the juvenile has been in any way, orally or in writing (by formal legal act) informed by the competent authorities that he/she is suspect or accused for committing a criminal offence. This means that all rights under the Directive 2016/800 apply to juvenile even before criminal proceedings have formally begun. See more Radić, op. cit., note. 4, p. $472-473$

76 Act on Police Affairs and Powers, Official Gazette No. 76/2009, 92/2014, 70/2019

77 See more: Petö Kujundžić, L., Djeca u kaznenom pravu, počinitelji i žrtve, Školska knjiga, Zagreb, 2019, p. $206-207$

78 Criminal Code, Art. 178. (1)

79 See: Criminal Code, Art. 178. (2) and (3). Criminal Code also has a special criminal offence that protects the secrecy of the proceedings in which the public is excluded. See: Criminal Code, art. 307

80 Turković, K. (ed.) et al., Komentar Kaznenog zakona, Narodne novine, Zagreb, 2013, p. 234-235 
The Directive also mentions the obligation of the MS regarding the media, which is regulated by special legal acts in Croatia, e.g. the Media Act (hereinafter: MA) ${ }^{81}$ One of the basic principles referring to the media mentioned in the MA is the protection of privacy: "The media are obliged to respect the privacy, dignity, reputation and honour of citizens, especially children, youth and families, regardless of gender and sexual orientation. It is prohibited to publish information that reveals the identity of the child, if it endangers the welfare of the child. ${ }^{82}$ However, even after ten years of application of this legislation, there is still an impression that the media publishers and editors have a tendency to disregard this act and violate it being aware that they are unlikely to suffer any serious consequences. ${ }^{83}$

Article 12 of the Electronic Media Act also states that "it is not allowed to publish information revealing the identity of a child under the age of 18 involved in cases of any form of violence, regardless of whether he is a witness, victim or perpetrator or the child has attempted or committed suicide, nor to give details of the child's family relationships and private life." 84 The Directive, like some other international documents such as the Guidelines, mentions that the MS should encourage the media to take self-regulatory measures, however some authors believe that in Croatia this cannot be achieved without the drastic court sentences. ${ }^{85}$

In the past few years, the Ombudsman for children has stated in her yearly reports that year after year there has been an increase in the inappropriate media coverage regarding the juvenile offenders that violates their right to privacy and dignity. The Ombudsman has repeatedly warned the editors and regulatory authorities of media outlets that, while reporting about the juveniles suspected or accused of a criminal offence, they must be aware of their particular responsibility because their negative attitude towards the juvenile can provoke inappropriate and even violent reactions of the public towards the child. ${ }^{86}$

Despite the fact that the reports from various state bodies have reported an increase in the violation of the juvenile's right to privacy, the data on the committed criminal offences stated in Art. 178 of the Criminal Code show otherwise. In the

Media Act, OG 59/04, 84/11, 81/13

Media Act, Art. 16

See: Report on the work of the Ombudsman for Children, Zagreb, 2019, p. 163

Electronic Media Act, OG 153/09, 84/11, 94/13 and 136/13, Art. 12

85 See: Hrabar, D., Zaštita djece u kaznenom postupku u promišljanjima o pravosudu nakolonjenom djeci, Godišnjak Akademije pravnih znanosti Hrvatske, vol. IX, no. 1, 2018, p. 10

86 See: Report on the work of the Ombudsman for Children, Zagreb, 2018, , p. 110; Report on the work of the Ombudsman for Children, Zagreb, 2018, Zagreb, p. 127-128 
period from 2014 to 2019 , only four judgements were passed for the criminal offence of violation of child's privacy. ${ }^{87}$

In the past years, there have been some unfavourable examples of media coverage of cases involving juveniles. In Croatia, a particular case of a group rape has aroused public interest because the victim and two suspects were under 18 years of age. ${ }^{88}$ This case resulted in a number of newspaper articles that analysed every detail of the case. When the media reported that the judge had decided that the suspects from the case would not be held in pre-trail detention, a major protest was held with the aim to influence the judge and change that decision. The President of the Republic of Croatia ${ }^{89}$ and the Ministry of Justice also commented on the case and the civil society organisations demanded that the Minister "intervene" in the case..$^{90}$ The case became a political issue that showed how little trust the public has in the justice system. The way in which the media reported about the case was particularly disturbing: new articles have been emerging on every internet portal for days, reporters were trying to find out the judge`s decision beforehand, locate the parents of the suspects, speak to the victim, they even visited the scene of the crime and interviewed some of the locals, discussed and revealed evidence of the case, and revealed the identity of the suspects on social media. ${ }^{91}$ This happened in

87 See: Croatian Bureau of Statistics, Adult perpetrators of Criminal Offences, Reports, Accusations and Convictions 2014-2019, Statistical Reports, Zagreb,2014-2020

88 Five young men, all young adults and juveniles, were accused of committing a criminal offence of rape and for criminal offence of threat against a 16-year-old girl. This criminal offence happened in a small village near Zadar where everybody knows everybody. Days after the news broke, a reporter came to the village to talk to the locals and try to find more information about the criminal offence. Sviličić, B., "Podignuta optužnica protiv petorice mladića zbog grupnog silovanja maloljetnice u okolici Zadra", Jutarnji list, 6. 5. 2020; [https://www.jutarnji.hr/vijesti/crna-kronika/podignuta-optuznica-protiv-petorice-mladica-zbog-grupnog-silovanja-maloljetnice-u-okolici-zadra-zlostavljanje-snimali-mobitelom-pa-ucjenjivali-zrtvu-10280362], accessed 20. June 2020

89 Ježovita, M., "Zgrožena sam viješću o zlostavljanju i ucjeni maloljetnice", Večernji list, 19. 10. 2019., [https://www.vecernji.hr/vijesti/zgrozena-sam-vijescu-o-zlostavljanju-i-ucjeni-maloljetnice-1352119], accessed 20. June 2020

90 Večenji list, "Ministre Bošnjakoviću, morat će te djelovati osobno i izravno na slučaj silovanja u Zadru”, 14. 10. 2019., [https://www.vecernji.hr/vijesti/ministre-bosnjakovicu-morat-cete-djelovati-osobno-i-izravno-na-slucaj silovanja-u-zadru-1352052], accessed 20. June 2020. Večernji list, "Udruge civilnog društva traže stegovni postupak protiv suca koji je pustio osumnjičene za silovanje”, 14. 10. 2019., [https:// www.vecernji.hr/vijesti/udruge-civilnog-drustva-traze-stegovni-postupak-protiv-suca-koji-je-pustio osumnjicene-za-silovanje-1352167], accessed 20. June 2020

91 Šarić, F.; Ježovita, M., "Naslovi su bombastični, sudac je zaključio da nema opasnosti od ponavljanja djela", Večernji list, 14. 10. 2019; [https://www.vecernji.hr/vijesti/zadarski-sud-osumnjiceni-su-pusteni-jer-nema-opasnosti-od-ponavljanja-kaznenog-djela-1352101]; Nevešćanin, I., "Strava kod Zadra: sedmorica mladića godinu dana silovala 15-godišnjakinju, tukli je, snimali mobitelom i ucjenjivali!; Sudac ih pustio da se brane sa slobode iako žrtva živi u istome mjestu!?", Slobodna Dalmacija, 14. 10. 2019, [https://slobodnadalmacija.hr/vijesti/crna-kronika/strava-kod-zadra-sedmorica-mladica-godinu-dana-silovala-15-godisnjakinju-tukli-je-snimali-mobitelom-i-ucjenjivali-sudac-ih-pustio-da-se-brane-sa- 
a case where everybody involved should have respected the privacy of the victim and the suspects involved in the case. This case particularly shows how little importance the right to the protection of privacy has in practice, because the media and the general public tend to forget about the juveniles' rights and the consequences that the disclosure of too much information about their lives has on their future development, feelings and life in general.

\section{CONCLUSION}

Juveniles have been recognised as vulnerable persons who need help and protection in situations when they are considered suspects or accused of committing a criminal offence. When dealing with juveniles during criminal proceedings, all persons involved should take into account their young age, level of maturity and intellectual and emotional capacities, which means that the criminal proceeding must be coordinated in order to support the best interests of the juvenile. The right to the protection of privacy is one of the rights that has often been neglected or disregarded by the people involved in the criminal proceeding. This right is particularly important for the juvenile because if their right to privacy is violated, the consequences can rarely be rectified. Once they have been labelled as "problematic" or "criminal" within their social environment, it may be difficult to change that label and the ensuing stigmatisation, especially for the juveniles who are more susceptible to the opinions of others, especially their peers because they want to be accepted.

Therefore, it is important to ensure the protection of privacy and personal data of juveniles during all stages of criminal proceedings in accordance with the national law, especially at the beginning of the criminal proceeding when they are most vulnerable. The Member States must ensure that the court and other hearings involving a suspect/accused juvenile are conducted behind the closed doors (in camera), while the exceptions to this rule should be very limited and clearly specified by law. In addition, only a limited number of people listed in the national legislation should have access to a court hearing and they should be warned that it is prohibited to reveal any information that could disclose juvenile's identity to the public. Another important issue is to try to make the court hearing more informal because in an informal atmosphere, with a limited number of participants and less

slobode-iako-zrtva-zivi-u-istome-mjestu-627862]; Nevešćanin, I., "Za monstruozan zločin u Zadru postoje čvrsti dokazil; Naši izvori oštro demantiraju sud: Istražitelji posjeduju snimke svih grupnih silovanja. Sudac je momke morao zadržati iza rešetaka!", Slobodna Dalmacija”, 16. 10. 2019. [https:// slobodnadalmacija.hr/vijesti/crna-kronika/za-monstruozan-zlocin-u-zadru-postoje-cvrsti-dokazi-nasi-izvori-ostro-demantiraju-sud-istrazitelji-posjeduju-snimke-svih-grupnih-silovanja-sudac-je-momke-morao-zadrzati-iza-resetaka-628428], all websites accessed 20. June 2020 
social and physical distance between the participants, there is a better chance that the juvenile will fully and effectively participate in the criminal proceeding.

Furthermore, special attention should be attributed to the media. The Member States should encourage the media to adopt self-regulatory measures and monitor their operation in practice or even prescribe legislative rules that the media must comply with when reporting about the cases involving a suspect/accused juvenile. In addition, the media employees should undergo trainings on juvenile offenders' rights for the purpose of relevant media reporting. The legislation should provide for a limited access to all records or documents containing personal and sensitive data of juveniles and ensure that all persons involved in the process must abide by the strict rules of confidentiality.

In most European countries, all these rules have already been incorporated in the legislation, however, this right is still frequently violated in practice. The Croatian legislation is fully in line with the requirements of the international documents and the Directive, and, in some respects, even better regulated with a higher standard for the protection of privacy. However, some legal professionals, journalists and other persons involved in the judicial process still do not understand the importance of this right and how their actions can influence the juveniles' future life and development. The consequences of violation of this right can be difficult for the juvenile and, most importantly, they cannot be remedied. Hence, education is a key step in ensuring the exercise of this right in practice. The Member States should ensure that the media workers, social workers, legal professionals, police officers and other participants in the judicial system who work with juveniles are systematically educated about the juveniles`right to privacy during criminal proceedings.

\section{REFERENCES}

\section{BOOKS AND ARTICLES}

1. Carić, A., Kazneni postupak prema maloljetnicima, Split, 2004

2. Carić, A.; Kustura, I., Kamo ide hrvatsko maloljetničko kazneno zakonodavstvo? - $2^{\text {nd }}$ part, Zbornik radova PF Split, vol. 47, no. 4, 2010, p. 779. -820

3. Cras, S., The Directive on Procedural Safeguards for Children who Are Suspects or Accused Persons in Criminal Proceedings, Genesis and Descriptive Comments Relating to Selected Articles, Eucrim, no. 2, 2016, p. 109-120

4. Croatian Bureau of Statistics, Adult perpertrators of Criminal Offences, Reports, Accusations and Convictions 2014- 2019., Statistical Reports, Zagreb, 2014. - 2019

5. Cvjetko, B.; Singer, M., Kaznenopravna odgovornost mladeži u praksi i teoriji s prilozima $i$ literaturom, Organizator, Zagreb, 2011 
6. de Vocht D., et al., Procedural Safeguards for Juvenile Suspects in Interrogations: A Look at the Commission Proposal in Light of an EU Comparative Study, New journal of European criminal law, vol. 5, no. 4, 2014, p. 480-506

7. Derenčinović, D.; Getoš, A.M., Uvod u kriminologiju s osnovama kaznenog prava, Zagreb, 2008

8. Gabelica Šupljika, M., Psihološki aspekt prikaza djeteta u medijima, u Zaštita privatnosti djece u medijima, Zbornik priopćenja s tribine, Pravobranitelj za djecu, Zagreb, 2009, p. 19-32

9. Gensing, A., Criminal procedure; in: Dünkel, F., et al., (eds.), Juvenile Justice Systems in Europe, Current Situation and Reform Developments, vol. 4, 2011, Forum Verlag Godesberg, p. $1607-1647$

10. Horvat, L., Postupovna jamstva za djecu koja su osumnjičena ili optužena u kaznenim postupcima sukladno Direktivi 2016/800/EU, HLJKPP; vol. 25, no. 2, 2018, p. 575-603.

11. Hrabar, D., Zaštita djece u kaznenom postupku u promišljanjima o pravosudu nakolonjenom djeci, Godišnjak Akademije pravnih znanosti Hrvatske, vol. IX, no. 1, 2018, p. 1-26

12. Kovačević, M., Maloletničko pravosude u Evropi i maloletnici kao aktivni učesnici krivičnog postupka, Zbornik PF u Splitu, vol. 51, no. 4, 2014, p. 879-894

13. Liefaard, T.; van den Brink, Y., Juveniles' Right to Counsel during Police Interrogations: An Interdisciplinary Analysis of a Youth-Specific Approach, with a Particular Focus on the Netherlands, Erasmus Law Review, December 2014, no. 4, p. 206-218

14. Manual: Can anyone hear me?, Participation of children in juvenile justice: A manual on how to make European juvenile justice systems child-friendly, IJJO, Published by the International Juvenile Justice Observatory (IJJO), 2016, Belgium

15. Petö Kujundžić, L., Djeca u kaznenom pravu, počinitelji i žrtve, Školska knjiga, Zagreb, 2019

16. Prijedlog Zakona o izmjenama ZSM-a, Vlada Republike Hrvatske, lipanj 2019, Zagreb

17. Radić, I., Right of the child to information according to the Directive 2016/800/EU on procedural safeguards for children who are suspects or accused persons in criminal proceedings, in: Duić, D.; Petrašević, T. (eds.), EU and comparative law issues and challenges series, Issue 2, 2019, p. 468-488

18. Rap, S., A Children's Rights Perspective on the Participation of Juvenile Defendants in the Youth Court, International Journal of Childrens s Rights, vol. 24, 2016, p. 93-112

19. Rap, S., et al., White Paper on the EU Directive 2016/800, Key aspects, priorities and challenges for implementation in the EUMS, IJJO

20. Rap, S.; Zlotnik, D., The Right to Legal and Other Appropriate Assistance for Child Suspects and Accused Reflections on the Directive on Procedural Safeguards for Children who are Suspects or Accused Persons in Criminal Proceedings, European Journal of Crime, Criminal Law and Criminal Justice, vol. 26, 2018, p. 110-131

21. Summary of contextual overviews on children's involvment in criiminal judical proceedings in the 28 MS of the EU, European Commission - Directorate-General for Justice, Luxembourg, Publications Office of the European Union, 2014

22. Turković, K. (ed.), et al., Komentar Kaznenog zakona, Narodne novine, Zagreb, 2013 


\section{INTERNATIONAL DOCUMENTS}

1. Convention on the Rights of the Child (CRC,) General Assembly Resolution 44/25 of 20 November 1989, entry into force 2 September 1990

2. Guidelines of the Committee of Ministers of the Council of Europe on child-friendly justice, adopted by the Committee of Ministers of the Council of Europe on 17 November 2010 and explanatory memorandum. Council of Europe Publishing, 2010

\section{EU LAW}

1. Charter of the Fundamental Rights of the EU, OJ C 326/395, 26. 12. 2012

2. Directive 2016/800/EU of the European Parliament and of the Council of the 11 May 2016 on the procedural safeguards for children who are suspects or accused persons in criminal proceedings (21.5.2016), OJ L 132/1

3. Recommendation CM/Rec (2008) 11 of the Committee of Ministers to member states on the European Rules for juvenile offenders subject to sanctions or measures, Adopted by the Committee of Ministers on 5 November 2008 at the 1040th meeting of the Ministers' Deputies

4. Recommendation CM/Rec (2017) 3 on the European Rules on community sanctions and measures, Adopted by the Committee of Ministers on 22 March 2017 at the 1282nd meeting of the Ministers' Deputies

5. Recommendation No. R (87)20 of the Committee of Ministers to member states on social reactions to juvenile delinquency, Adopted by the Committee of Ministers on 17 September 1987at the 410th meeting of the Ministers' Deputies

\section{LIST OF NATIONAL REGULATIONS, ACTS AND COURT DECISIONS}

1. Act on Police Affairs and Powers, Official Gazette No. 76/2009, 92/2014, 70/2019

2. Constitution of the Republic of Croatia, Official Gazette, No. 56/90, 135/97, 08/98, $113 / 00,124 / 00,28 / 01,41 / 01,55 / 01,76 / 10,85 / 10,05 / 14$

3. Criminal Code, Official Gazette No. 125/11., 144/12., 56/15., 61/15., 101/17., 118/18., $126 / 19$.

4. Electronic Media Act, Official Gazette No. 153/09, 84/11, 94/13, 136/13

5. Media Act, Official Gazette No. 59/04, 84/11, 81/13

6. Youths Courts Act,Official Gazette No. 84/2011, 143/2012, 148/2013, 56/2015, 126/2019

\section{CASE LAW OF THE ECtHR}

1. European Convention on Human Rights, opened for signature in Rome on 4 November 1950 and came into force in 1953. [https://www.echr.coe.int/Documents/Convention_ ENG.pdf], accessed 20. June 2020

2. Adamkiewicz vs. Poland, 2 March 2010, appl. No. 54729/00

3. Blokhin v. Russia, 14 November 2013, appl. No. 47152/06

4. S.C. vs. U.K., ECHR 15.06.2004, appl. No. 60958/00 
5. T and V vs. U.K., ECHR 16.12.1999, appl. No. 24724/94

\section{WEBSITE REFERENCES}

1. Guide on Article 6 of the Convention - Right to a fair trial (criminal limb), European Court of Human Rights, Council of Europe, updated on 31 December 2019, [https://www.echr. coe.int/Documents/Guide_Art_6_criminal_ENG.pdf], accessed 20. June 2020

2. Guidlines on child friendly legal aid, UNHCR, UNICEF's Europe and Central Asia Regional Office (ECARO), October 2018, [https://www.unicef.org/eca/sites/unicef.org.eca/ files/2018-11/Guidelines\%20on\%20Child-Friendly\%20Legal\%20Aid\%20UNICEF\%20 ECARO\%202018.pdf ], accessed 20. June 2020

3. Ježovita, M., "Zgrožena sam viješću o zlostavljanju i ucjeni maloljetnice”, Večernji list, 19. 10. 2019; [https://www.vecernji.hr/vijesti/zgrozena-sam-vijescu-o-zlostavljanju-i-ucjeni-maloljetnice-1352119], accessed 20. June 2020

4. Nevešćanin, I., "Strava kod Zadra: sedmorica mladića godinu dana silovala 15-godišnjakinju, tukli je, snimali mobitelom i ucjenjivali!; Sudac ih pustio da se brane sa slobode iako žrtva živi u istome mjestu!?", Slobodna Dalmacija, 14. 10. 2019, [https://slobodnadalmacija.hr/vijesti/ crna-kronika/strava-kod-zadra-sedmorica-mladica-godinu-dana-silovala-15-godisnjakinju-tukli-je-snimali-mobitelom-i-ucjenjivali-sudac-ih-pustio-da-se-brane-sa-slobode-iakozrtva-zivi-u-istome-mjestu-627862], accessed 20. June 2020

5. Nevešćanin, I., "Za monstruozan zločin u Zadru postoje čvrsti dokazi!; Naši izvori oštro demantiraju sud: Istražitelji posjeduju snimke svih grupnih silovanja. Sudac je momke morao zadržati iza rešetaka!", Slobodna Dalmacija, 16. 10. 2019; [https://slobodnadalmacija.hr/vijesti/crna-kronika/za-monstruozan-zlocin-u-zadru-postoje-cvrsti-dokazi-nasi-izvori-ostro-demantiraju-sud-istrazitelji-posjeduju-snimke-svih-grupnih-silovanja-sudac-je-momke-morao-zadrzati-iza-resetaka-628428], accessed 20. June 2020

6. Report on the work of the Ombudsman for Children, Zagreb, 2018, [https://dijete.hr/izvjesca/izvjesca-o-radu-pravobranitelja-za-djecu/], accessed 20. June 2020

7. Report on the work of the Ombudsman for Children, Zagreb, 2019, [https://dijete.hr/izvjesca/izvjesca-o-radu-pravobranitelja-za-djecu/], accessed 20. June 2020

8. Šarić, F.; Ježovita, M., "Naslovi su bombastični, sudac je zaključio da nema opasnosti od ponavljanja djela”, Večernji list, 14. 10. 2019; [https://www.vecernji.hr/vijesti/zadarski-sud-osumnjiceni-su-pusteni-jer-nema-opasnosti-od-ponavljanja-kaznenog-djela-1352101], accessed 20. June 2020

9. Sviličić, B., "Podignuta optužnica protiv petorice mladića zbog grupnog silovanja maloljetnice u okolici Zadra”, Jutarnji list, 6. 5. 2020; [https://www.jutarnji.hr/vijesti/crna-kronika/podignuta-optuznica-protiv-petorice-mladica-zbog-grupnog-silovanja-maloljetnice-u-okolici-zadra-zlostavljanje-snimali-mobitelom-pa-ucjenjivali-zrtvu-10280362], accessed 20. June 2020

10. UN Committee on the Rights of the Child (CRC), General comment No. 10 (2007): Children's Rights in Juvenile Justice, 25 April 2007, CRC/C/GC/10, available at: [https:/www. refworld.org/docid/4670fca12.html], accessed 13. July 2020

11. Večernji list, "Ministre Bošnjakoviću, morat će te djelovati osobno i izravno na slučaj silovanja u Zadru”, 14. 10. 2019, [https://www.vecernji.hr/vijesti/ministre-bosnjakovicu-mor- 
at-cete-djelovati-osobno-i-izravno-na-slucaj silovanja-u-zadru-1352052], accessed 20. June 2020

12. Večernji list, "Udruge civilnog društva traže stegovni postupak protiv suca koji je pustio osumnjičene za silovanje", 14. 10. 2019, [https://www.vecernji.hr/vijesti/udruge-civilnog-drustva-traze-stegovni-postupak-protiv-suca-koji-je-pustioosumnjicene-za-silovanje-1352167], accessed 20. June 2020 